\title{
STRUCTURILE DE GENIU DIN CADRUL COMANDAMENTELOR NATO ÎN CONFORMITATE CU NOILE PREVEDERI DOCTRINARE
}

\author{
MILITARY ENGINEERING STRUCTURES WITHIN NATO COMMANDS \\ IN ACCORDANCE WITH THE NEW DOCTRINAL PROVISIONS
}

\author{
Col.drd. Cristian Gabriel CÎRJĂU*
}

\begin{abstract}
Conform directivelor Comitetului Militar NATO, asigurarea unui sprijin de geniu eficient necesită atât structuri adecvate de conducere și de stat major de geniu, cât și aranjamente de comandă-control (C2) la toate nivelurile. Aceste aranjamente C2, organizarea structurală și atribuțiile lor generale sunt reglementate în noua doctrină NATO pentru geniu, prin care se recomandă implementarea prevederilor în organizarea atât a comandamentelor NATO, cât și a comandamentelor din cadrul armatelor naționale membre ale NATO. În rândurile următoare, mi-am propus să fac o scurtă prezentare a modului de organizare a structurilor de geniu din cadrul comandamentelor NATO, de la diferite niveluri ierarhice, în conformitate cu noile prevederi doctrinare, și să fac, de asemenea, referiri la relațiile de cooperare și câteva precizări cu privire la atribuțiile generale ale acestora. Întrucât noile prevederi doctrinare NATO, pe linie de geniu, sunt în curs de implementare și în armata română, urmează să fie făcute propuneri factorilor decidenți pentru modificarea structurilor de comandament de geniu din armata română, astfel încât acestea să fie similare cu cele din cadrul comandamentelor NATO.
\end{abstract}

According to the directives of the NATO Military Committee, ensuring the effective engineering support required by the military engineering command and staff structures, as well as command-control (C2) arrangements are performed at all levels. These C2 arrangements, the structural organization, and their general attributions are regulated in the new NATO Doctrine for Military Engineering, which recommends the implementation of the provisions in the organization of NATO commands, as well as of the commands within the NATO national armies. In the following lines, I intend to make a short presentation of the organization of military engineering structures within NATO commands, from different hierarchical levels, under the new doctrinal provisions, also, references to cooperation relations and some clarifications with on their general responsibilities. As the new NATO doctrinal provisions on the military engineering branch are being implemented in the Romanian Army, proposals are to be made to the decision-makers, to modify the military engineering command structures in the Romanian Army, to be similar to those within the NATO commands.

Cuvinte-cheie: NATO; ACO; ACT; SHAPE; JFC; LANDCOM; comandă-control; arma geniu.

Keywords: NATO; ACO; ACT; SHAPE; JFC; LANDCOM; command-control; military engineering branch.

Activitatea genistică este o funcțiune în sprijinul operațiilor și reprezintă totalitatea măsurilor întreprinse în vederea modelării, configurării mediului fizic în care sunt executate operații. Ca funcțiune, este condusă și coordonată de către personal/structuri de comandament de geniu. În conformitate $\mathrm{cu}$ directivele Comitetului Militar, asigurarea unui sprijin de geniu eficient necesită atât structuri adecvate de conducere și de stat major de geniu, cât și aranjamente de comandă-control (C2) la toate nivelurile ${ }^{1}$. Aceste aranjamente C2,

\footnotetext{
*Statul Major al Apărării

e-mail:cirjau_cristian@yahoo.com
}

organizarea structurilor de comandament de geniu și atribuțiile lor generale sunt reglementate în noua doctrină NATO pentru geniu (AJP-3.12 (C), Allied Joint Doctrine for Military Engineering, 2021), prin care se recomandă implementarea prevederilor în organizarea atât a comandamentelor NATO, cât și a comandamentelor din cadrul armatelor naționale membre ale NATO.

În rândurile următoare, mi-am propus să fac o scurtă prezentare a modului de organizare a structurilor de geniu din cadrul comandamentelor NATO, de la diferite niveluri ierarhice ${ }^{2}$, în conformitate cu noile prevederi doctrinare și, de asemenea, scurte referiri la relațiile de cooperare pe orizontală sau verticală și câteva precizări 
cu privire la atribuțiile generale ale acestora, în funcție de informatiile de care dispun la acest moment. În general, informațiile despre structurile organizatorice ale unor entități din cadrul comandamentelor/statelor majore au un nivel de secretizare ridicat, așa că informațiile de care dispun nu sunt întotdeauna complete. Totuși, prin corelarea și analiza celor disponibile, consider că am reușit să fac deducții corespuzătoare cu privire la organizarea și rolul structurilor de geniu din cadrul comandamentelor NATO.

Avându-se în vedere caracterul de noutate, pentru armata română, a prevederilor doctrinare ale NATO pe linie de geniu, prin analiza din cuprinsul articolului am urmărit o prezentare cât mai pertinentă a respectivelor prevederi, de natură să-mi permită formularea unor propuneri, adresate factorilor decidenți, de modificare a structurilor de comandament de geniu, din armata română, astfel încât acestea să fie similare cu cele din cadrul comandamentelor NATO.

\section{Structura militară de comandă NATO}

Organizaţia Tratatului Nord-Atlantic (NATO) este o alianţă formată din 30 de state din Europa şi din America de Nord. Scopul esenţial al NATO este acela de a asigura libertatea şi securitatea tuturor membrilor săi prin mijloace politice şi militare, în conformitate $\mathrm{cu}$ prevederile tratatului şi $\mathrm{cu}$ prevederile Cartei Naţiunilor Unite.

Structurile civile și militare create în cadrul NATO permit ţărilor membre să coopereze, în scopul îndeplinirii acestor sarcini fundamentale. Prin intermediul lor, se armonizează interesele în domeniul politic, economic, dar și în alte domenii nonmilitare. De asemenea, se concep planuri comune de apărare prin care se stabilesc forțele, infrastructura, echipamentele şi toate facilităţile necesare ducerii operaţiilor militare. ${ }^{3}$

Structura militară de comandă a NATO (NATO's Military Command Structure) este coloana vertebrală a Organizaţiei. Este compusă din comandamente multinaționale permanente, organizate la nivelurile de comandă strategic, operativ și tactic, distribuite geografic și finanțate conform procedurilor adoptate ${ }^{4}$. Aceasta oferă posibilitatea tuturor aliaților de a participa și de a contribui la comanda și controlul operațiilor, misiunilor și activităților în toate domeniile militare ale Alianței.
În urma Summiturilor care au avut loc în ultimii ani de zile, structura militară de comandă a NATO a fost reformată și s-a creat un sistem de comandă robust, agil și eficient. De asemenea, aceste reforme au îmbunătățit interoperabilitatea structurii de comandă NATO cu structura de forțe NATO (NATO Force Structure). Aceasta din urmă este un grup distinct de forțe naţionale și multinaţionale aliate, cât și comandamentele puse la dispoziția Alianței în mod permanent sau temporar.

Structura militară de comandă a NATO se află sub autoritatea Comitetului Militar, cea mai înaltă entitate militară a NATO, compus din șefii apărării din toate cele treizeci de țări membre, care, la rândul lui, se află sub autoritatea Consiliului Nord-Atlantic (North Atlantic Council - NAC).

La nivel strategic, identificăm structura de comandă pentru operații, respectiv Allied Command Operations - ACO - și structura de comandă pentru transformarea Alianței, respectiv Allied Command Transformation - ACT.

ACO este organizat pe trei niveluri (strategic, operativ și tactic) și are în organizare atât comandamente, cât și alte structuri de sprijin. ACO, aflat sub comanda Comandantului Suprem al Forțelor Aliate din Europa (SACEUR), este responsabil pentru planificarea și executarea tuturor operațiilor militare NATO, în conformitate cu instructiunile Consiliului Nord-Atlantic 5 .

ACT este în fruntea transformării militare a NATO. Se află sub comanda Comandantului Suprem al Forțelor Aliate pentru Transformare (SACT), care își exercită responsabilitățile din sediul central din Norfolk, Virginia (SUA). Principalele responsabilități ale ACT includ educaţia, instruirea, exercițiile și promovarea interoperabilității. ${ }^{6}$

În rândurile următoare, vom face referire doar la comandamentele pe linie de operații, unde identificăm structurile de geniu care fac obiectul acestei analize.

La nivel strategic, există Comandamentul Suprem al Forțelor Aliate din Europa (Supreme Headquarters Allied Powers Europe - SHAPE) de lângă Mons, Belgia, de unde SACEUR își exercită responsabilităţile.

La nivelul următor de comandă, nivelul operativ, se află trei Comandamente de Forțe Întrunite (Joint Force Commands - JFCs), care sunt situate în Brunssum (Olanda), Napoli (Italia) și Norfolk (SUA). Aceste comandamente sunt conduse de un 
comandant al forțelor întrunite, care este sprijinit de personalul de stat major din cadrul acestora. Acestea pot fi dislocabile sau nedislocabile.

La nivel tactic, există Comandamentul Aliat al Forțelor Terestre din Izmir (Turcia), Comandamentul Aliat al Forțelor Navale din Northwood (Anglia) și Comandamentul Aliat al Forțelor Aeriene din Ramstein (Germania).

La toate acestea, putem adăuga și Comandamentele Corpurilor Aliate (Rapid Dislocabile, EUROCORPS, Multinaționale) și, de asemenea, Comandamentele Diviziilor Multinaționale, la care vom face referire în rândurile următoare.

\section{Structurile de geniu \\ din cadrul comandamentelor NATO}

După cum am precizat în rândurile de mai sus, Alianța se bazeză pe o combinație de structuri de conducere, prin intermediul cărora se asigură comanda și controlul pentru executarea operațiilor militare. Pentru asigurarea unui sprijin de geniu adecvat, este necesară o coordonare eficientă la toate aceste niveluri de comandă. Cea mai eficientă întrebuințare a tuturor resurselor de geniu se realizează, în conformitate cu prevederile doctrinare $^{7}$, de către un șef al geniului (consilier superior pe linie de geniu), existent la fiecare nivel de comandă, care are autoritatea tehnică și de coordonare pentru toate resursele de geniu aflate la dispoziție și care este în măsură să organizeze capabilitățile multinaționale, în conformitate cu priorităţile generale ale comandantului, pe parcursul unei operații. Pentru gestionarea tuturor problemelor pe linie de geniu, șeful geniului este sprijinit de personal de stat major specializat și încadrat în structuri de comandament dedicate.

\section{Șeful geniului. Roluri și responsabilități ${ }^{8}$}

Şeful geniului este consilier pe linie de geniu la toate nivelurile de comandă. MC 0560/2, Military Committee Policy for Military Engineering prevede că toți comandanții au nevoie de un consilier pe linie de geniu, care trebuie să fie sprijinit de un personal de stat major, pentru asigurarea utilizării eficiente a resurselor și capabilităților de geniu care sunt limitate. Eficacitatea șefului geniului și a personalului specializat de la fiecare nivel de comandă va depinde nemijlocit de o bună coordonare și de o strânsă cooperare între personalul de la toate nivelurile și între toate componentele.
Nivelul strategic - la acest nivel, șeful geniului, împreună cu personalul din subordine contribuie, ca experți, la procesul de planificare operaţională. Ei confirmă faptul că vor fi generate capabilităţi de geniu adecvate într-un timp util pentru a îndeplini cerințele pe termen scurt, mediu și lung. Specialiștii de geniu de la acest nivel de comandă lucrează îndeaproape cu Statul Major Militar Internațional şi cu Înalții Reprezentanţi Naţionali de Geniu (Senior National MILENG Representatives). De asemenea, colaborează cu personalul național de planificare pentru capabilităţile de geniu destinate executării operaţiilor militare.

Nivelul operativ - la acest nivel, șeful geniului este principalul consilier al comandantului forței întrunite (Joint Force Commander - JFC) pentru toate problemele pe linie de geniu. Acesta coordonează alocarea judicioasă a resurselor de geniu pentru a îndeplini obiectivele stabilite. Sarcinile lui principale constau în identificarea cerinţelor pentru sprijinul de geniu, consilierea comandantului forțelor întrunite cu privire la disponibilitatea capabilităților și resurselor de geniu şi coordonarea efortului pe linie de geniu pe întreg teritoriul componentelor (terestre, navale, aeriene ș.a.). Şeful geniului, în numele comandantului forțelor întrunite, va avea autoritatea de coordonare, pentru a asigura cea mai eficientă utilizare a capabilităților și resurselor. Aceste forțe pot include capabilităţi de trecere peste obstacole mari (poduri modulare, poduri de pontoane peste cursurile de apă); capabilităţi de contramobilitate; capabilităţi specializate de neutralizare a dispozitivelor explozive (Explosive Ordnance Disposal - EOD); capabilități specializate de construcții etc.

Şeful geniului trebuie să se asigure că directivele de la nivelul strategic sunt transmise sub forma unor sarcini clare tuturor forțelor geniu. De asemenea, comandanții de la toate nivelurile trebuie să cunoască foarte bine care sunt priorităţile, astfel încât să asigure utilizarea eficientă a capabilităților de geniu. Acestea trebuie planificate centralizat de către șeful geniului al forțelor întrunite și personalul din subordine, pe parcursul întregului proces de planificare operațională. Sarcinile trasate se vor executa descentralizat la cel mai mic nivel de comandă. Aceasta poate include capabilitățile de geniu ale forțelor NATO, ale națiunilor gazdă, contractanților, organizațiilor și agențiilor internaționale cu care cooperăm. Efortul sprijinului 
de geniu poate fi schimbat între componente, în conformitate $\mathrm{cu}$ efortul principal, stabilit de comandantul forței întrunite.

Nivelul tactic - șeful geniului de la nivel tactic este responsabil pentru coordonarea structurilor de geniu care execută sarcini specifice în domeniile mobilității, contramobilității, menținerii capacității operaționale și sprijinului de geniu general, sarcini care afectează mediul de operare. La acest nivel, în lipsa unui șef al geniului, rolul poate fi asumat temporar de către un comandant al unei structuri de geniu.

\section{Organizarea structurilor de comandament} de geniu ${ }^{9}$

Structurile de comandament de geniu, bine configurate și robuste, sunt esențiale la comandamentele de toate nivelurile. Acestea sunt organizate într-un Serviciu independent care trebuie să includă obligatoriu următoarele capabilități:

\section{Planificare operații de geniu $^{10}$ (secție/biroul compartiment)}

Personalul de geniu contribuie la procesul de planificare și furnizează datele genistice necesare atât pentru toate operațiile potențiale în cadrul apărării colective, cât și pentru managementul crizelor. Structura de geniu trebuie să fie capabilă să consilieze, să planifice, să execute și să raporteze activitățile tuturor geniștilor. În funcție de situația tactică și de tipul operației, poate fi necesar ca structura să fie augmentată cu personal de specialitate suplimentar. Implicarea personalului de geniu din cadrul comandamentelor în activitățile de planificare este esențială pentru toate operatiiile, în vederea determinării resurselor de geniu necesare.

\section{Conducere operații de geniu}

Sarcina principală a personalului de geniu din cadrul comandamentelor este sincronizarea eforturilor genistice și consilierea $\mathrm{cu}$ privire la angajarea unităţilor de geniu în operații. De asemenea, deține informații actualizate cu privire la capacitatea operatională a acestora, necesare planificării și executării operaţiilor curente. În functiie de nevoi, cu respectarea politicilor de securitate NATO, poate disemina anumite informații genistice actorilor cheie non-NATO, pentru realizarea unui sprijin de geniu adecvat.

\section{Informații}

Personalul de geniu din cadrul structurilor de comandament cooperează permanent cu personalul de informații din cadrul structurilor de informaţii dedicate și gestionează permanent toate informațiile genistice. Informațiile de geniu deținute sunt diseminate, în funcție de nevoi, pe parcursul tuturor fazelor operației. Aceste informații genistice se referă la elemente de infrastructură rutieră, aeroportuară, portuară, de cale ferată, lucrări de artă, date despre cursurile de apă, capabilitățile de geniu ale adversarului, date despre amenințările cu muniții explozive. Personalul de geniu contribuie cu informații necesare realizării imaginii operaționale comune.

\section{Infrastructură}

Personalul de geniu este la curent cu toate datele și informațiile despre infrastructura din zona de responsabilitate. Contribuie cu estimări la procesul de planificare operațională și, de asemenea, face propuneri cu privire la dezvoltarea acesteia, date necesare elaborării planurilor de dezvoltare a infrastructurii.

\section{Logistica}

Personaluldegeniudincadrul comandamentului este permanent la curent cu cerințele pentru resursele de geniu necesare în teatrul de operații. Cunoaște atât situația materialelor de geniu clasa a IV-a, cât și a celor naționale și, de asemenea, prioritățile de alocare.

\section{Neutralizare dispozitive explozive (EOD)}

In cadrul structurii de geniu se constituie o Celulă EOD care are rolul de a coordona și integra eforturile specialiștilor EOD pe linia sprijinului de specialitate în zona de operații alocată. Pentru o grupare de forțe întrunite multinaționale, se constituie o Celulă EOD multinațională, care asigură managementul elementelor EOD din cadrul comandamentelor de componente, a celor naționale din cadrul forței întrunite, a celor care aparțin națiunilor gazdă, cât și altor organizații. Prin intermediul acestei celule, șeful geniului are autoritatea tehnică și de coordonare a sprijinului EOD în toată zona de responsabilitate ${ }^{11}$. 


\section{Relația structurilor de comandament} de geniu de la diferite niveluri ierarhice ${ }^{12}$

La nivel strategic, personalul de geniu intermediază coordonarea activităţilor pe linie de geniu între nivelurile politico-militar și operativ, precum și cu alte organizații non-NATO. Şeful geniului din cadrul comandamentului de nivel strategic emite direcționări cu privire la capabilitățile de geniu în cadrul Procesului NATO de planificare a apărării, politica și evoluțiile doctrinare legate de arma geniu, aspecte legate de infrastructura de interes, planificarea şi conducerea, la nivel strategic, a tuturor aspectelor pe linie de geniu pe timpul desfăşurării operațiilor și exerciţiilor.

Planificarea la nivel strategic pe linie de geniu va defini cerințele generale pentru sprijinul de geniu pentru operațiile NATO și se asigură că sunt disponibile suficiente capabilități de geniu pentru comandantul de la nivel operativ.

Consilierea pe linie de geniu cu privire la cerințele de infrastructură operațională va ajuta personalul controlor financiar de la nivelul strategic în determinarea finanțării necesare. Cerințele generate în mod normal la nivel tactic sunt validate şi aprobate la nivel operativ și apoi transmise la nivel strategic. Acestea sunt analizate și, ulterior, înaintate pentru aprobare.

Directivele și îndrumările transmise de la nivel strategic către comandanții de la nivel operativ le permit acestora inițierea și desfăşurarea procesului de planificare operațională. În baza directivelor militare strategice, sunt planificate şi executate operațiile, incluzând și sprijinul de geniu, pentru a atinge obiectivele strategice stabilite. La nivel tactic, sarcinile/misiunile sunt planificate și executate în conformitate cu Planul de operaţii (OPLAN)/Ordinele de operații (OPORD) și ordinele ulterioare (FRAGO) primite ${ }^{13}$.

Șeful geniului de la nivel operativ va asigura consilierea comandantului forțelor întrunite cu privire la sarcinile pe linie de geniu și la prioritizarea acestora. De asemenea, va consilia și direcționa componentele operaționale pe toate domeniile de expertiză, pe linie de geniu și va aloca resursele de geniu aferente.

Sprijinul de geniu de la nivel tactic va crea efecte, iar acestea trebuie să susțină realizarea obiectivelor operative, contribuind la realizarea stării finale dorite.

\section{Structura de geniu din cadrul SHAPE}

În urma deciziilor luate la Summiturile NATO, structurile militare de comandă au trecut printr-un amplu proces de transformare. Concomitent cu aceasta, au suferit modificări organizatorice și structurile de comandament de geniu. Inițial, au avut o organizare mai simplă, dar având de gestionat mai multe domenii importante și complexe, a fost nevoie ca aceste structuri de comandament de geniu să fie reorganizate și diversificate.

Conform organizării SHAPE, din 2014 ${ }^{14}$, structura de geniu din cadrul acestui comandament de nivel strategic avea următoarea organizare:

Divizia Geniu Întrunit (Joint Engineering Division), organizată pe două servicii: Planuri de Geniu (Plans Branch) și Operații de Geniu (Operations Branch), era în cadrul Direcției Resurse (Resources Directorate), condusă de un general cu două stele ${ }^{15}$. Divizia Geniu Întrunit era condusă de un locțiitor al şefului de stat major pentru geniu, cu grad de general de brigadă, care avea rol și de ofițer senior de geniu (ACO Senior Joint Engineer).

Serviciul Planuri de Geniu (Plans Branch) era responsabil cu sprijinirea procesului de planificare la nivel strategic, prin furnizarea de date genistice și coordonarea tuturor contribuțiilor pe linie de geniu la toate planurile ACO. În plus, oferea expertiză de specialitate pentru politica, doctrina, planificarea apărării, generarea forței, instruirea, procedurile și standardizarea NATO pe linie de geniu. Coordona aspectele de infrastructură ale NSIP (NATO Security Investment Programme) în țările NATO, pachetele și planurile de capabilități ale comandamentelor NATO. De asemenea, planifica, dezvolta și implementa politicile, doctrinele, procedurile și standardele cu privire la cerințele de infrastructură pentru managementul acesteia și dezvoltarea capabilităților, cât și pentru protecția mediului.

Serviciul Operații de Geniu (Operations Branch) era responsabil cu sprijinul de geniu la nivel strategic pentru comanda și controlul tuturor operațiilor/exercițiilor și oferea feedback cu privire la toate lecțiile identificate/învăţate, pe linie de specialitate. Gestiona toate aspectele pe linie de geniu, necesare desfășurării pregătirii informative; gestiona și coordona aspectele de infrastructură ale NSIP în operații; asigura expertiză de specialitate pentru neutralizarea dispozitivelor explozive 
(EOD) și sprijinul de geniu pentru protecția forței, pentru contracararea dispozitivelor explozive improvizate (C-IED) și pentru operațiile de căutare militare (military search).

În ceea ce privește structura de geniu din cadrul SHAPE, în anul $2021^{16}$, ca urmare a transformărilor organizatorice care au avut loc pentru eficientizarea activităților și pentru a răspunde provocărilor mediului de securitate actual, în organizarea acestui comandament NATO de nivel strategic, identificăm Divizia Infrastructură şi Geniu (Infrastructure and Engineering Division/Strategic Enablement Directorate/SHAPE), care este condusă de un șef al geniului. Acestă divizie cuprinde mai multe servicii/ birouri, organizate astfel: Infrastructură și Mediu (Infrastructure and Environmental Branch); Planuri de Geniu (Plans); Operații de Geniu (Operations); Informații de Geniu (Intelligence); Logistică de Geniu (Logistics); Explosive Ordanance Disposal (EOD).

\section{Structurile de geniu}

din cadrul Comandamentelor Forțelor Întrunite

Comandamentul Forțelor Întrunite (Joint Force Command) activează la nivel operativ și este capabil să execute efectiv comanda și controlul asupra forțelor atribuite, cu scopul de a obține efecte operaționale în zona de operații întrunită atribuită (Joint Operating Area $)^{17}$. Relațiile cu alte structuri de comandă NATO (NATO Command Structure) și comandamentele structurilor de forțe NATO (NATO Force Structure Component Command Headquarters) sunt diferite, în funcție de situație: pace, criză sau conflict.

Comandamentul Forțelor Întrunite este condus de un comandant cu grad de general cu patru stele (există și locțiitor al comandantului - general cu trei stele), care este secondat de un șef de stat major (general cu două stele). În subordinea șefului de stat major, se află locțiitorii acestuia pe linie de planificare, operații și sprijin (generali cu o stea, șefi de direcție). În cadrul comandamentului, sunt reprezentate mai multe categorii de forțe, de bază fiind forțele terestre, aeriene și navale.

Direcțiile sunt împărțite în divizii de tip Joint (întrunit), conduse de ofițeri cu gradul de colonel. În cadrul Direcției sprijin (Support Directorate), există Divizia Geniu Intrunit (Joint Engineer Division). Direcția sprijin este responsabilă pentru planificarea, direcționarea, monitorizarea, evaluarea și coordonarea funcțiunilor staffului de sprijin.
Divizia Geniu Întrunit (Joint Engineer Divison) din cadrul Direcției sprijin este condusă de șeful geniului al forței întrunite (Joint Force Engineer - JFENGR), și, spre exemplu, în anul 2014 avea în organizare următoarele servicii/birouri: Operații de Geniu (Operations Branch); Planuri de Geniu (Plans Branch); Infrastructură (Infrastructure).

Divizia Geniu Intrunit este responsabilă cu asigurarea de consiliere pentru probleme care țin de sprijinul de geniu al forței și de sprijinul de geniu luptă pentru activități și operații NATO.

Structura de geniu era condusă de şeful geniului al forței întrunite. Acesta este responsabil cu asigurarea consilierii şi coordonării tuturor aspectelor de geniu pentru activitățile și operațiile NATO în cadrul zonei de operaţii întrunite, în teatru și pentru evenimente din afara acestor zone, în angajamentele de parteneriat NATO.

Comandantul forței întrunite va fi consiliat de şeful geniului cu privire la aspectele pe linie de geniu, legate de executarea responsabilităților/ sarcinilor operaționale. Prioritățilepentru asigurarea sprijinului de geniu vor fi determinate pe timpul procesului de planificare de la nivel operațiv. Șeful geniului acționează, de asemenea, ca autoritate de coordonare a capabilităților de geniu pentru toate componentele.

Șeful geniului pregătește îndrumările generale în domeniul sprijinului de geniu, furnizează datele genistice necesare elaborării concepției operației, planificării și organizării procesului de generare a forței și, în mod special, pentru generarea forțelor de geniu. El reprezintă autoritatea tehnică și de coordonare a mijloacelor/resurselor de geniu în cadrul grupării de forțe, în scopul de a asigura utilizarea eficientă a acestora, echilibrarea efortului de sprijin de geniu între componentele forței și orientarea efortului sprijinului de geniu, în funcție de necesităţile dictate de situația operativă.

Conform recomandărilor cuprinse în AJP-3.12 (C), Allied Joint Doctrine for Military Engineering din 2021, Divizia Geniu din cadrul Comandamentelor de Forțe Întrunite are următoarele structuri: Infrastructură și Mediu (Infrastructure and Environmental Branch); Planuri de Geniu (Plans Branch); Operații de Geniu (Operations Branch); Informații de Geniu (Intelligence); Logistică de Geniu (Logistics); Explosive Ordanance Disposal (EOD). 
Responsabilitățile acestor servicii/birouri sunt similare celor de la nivelul strategic, dar sunt adaptate nevoilor de la nivelul întrunit.

\section{Structura de geniu din cadrul LANDCOM}

Comandamentul Componentei Terestre (Land Component Command - LANDCOM) este responsabil pentru coordonarea și sincronizarea forțelor terestre NATO și partenere, cu scopul de a permite pregătirea, interoperabilitatea, standardizarea și gestionarea spațiului terestru ${ }^{18}$.

Acest comandament este condus de un comandant cu grad de general cu trei stele (există și locțiitor al comandantului - general cu două stele), care este secondat de un șef de stat major (general cu două stele). În subordinea șefului de stat major, se află locțiitorii acestuia pe linie de planificare, operații și sprijin (generali cu o stea, șefi de direcție).

Direcțiile sunt împărțite în divizii și sunt conduse de ofițeri cu gradul de colonel. În cadrul Direcției operații, există diviziile G.2-Informații, G.3-Operații și G. Geniu (GENG).

Divizia Geniu ( $G$ Engineering Division GENG Division) din cadrul LANDCOM este condusă de locțiitorul pentru geniu al șefului de stat major (Assistant Chief of Staff G Engineer - ACOS GENG), se află în organizarea Direcției operații (Operations Directorate) și are în compunere următoarele servicii/birouri ${ }^{19}$ : Operații și Instrucție (Operations \& Training Branch); Infrastructură și Planuri (Infrastructure \& Plans Branch); Coordonare/Protecția mediului (Coordination/ Environmental Protection Office).

Divizia Geniu are ca responsabilități curente monitorizarea și evaluarea necesarului de capabilități de geniu. Aceasta asigură consiliere și sprijin de specialitate pentru protecția forței, CIMIC și pentru alte domenii specializate, la nevoie. Asigură consiliere pe linie de geniu pentru probleme de protecție a mediului și coordonarea acestui domeniu. De asemenea, asigură feedback pentru geniștii din NATO cu privire la toate lecțiile identificate/învățate, pe linie de specialitate.

Divizia planifică, coordonează și sincronizează toate actiunile legate de sprijinul de geniu pentru a contribui la punerea în aplicare a planurilor de operații, care includ sprijinul de geniu pentru dezvoltarea și întreținerea infrastructurii în Zona de Operații Întrunită (Joint Operations Area -
JOA), cât și sprijinul pentru asigurarea libertății de manevră/mișcare. Geniștii sunt implicaţi în activitățile desfășurate la nivel strategic și operativ, în situația dislocării forțelor NATO. În plus, există probleme inerente de angajare tactică, ce trebuie înţelese pentru a aprecia pe deplin capabilităţile și capacitățile geniștilor, ca răspuns pentru angajare.

Locțiitorul pentru geniu al șefului de stat major (ACOS GENG) este șef al geniului (Chief Engineer) și consilier superior (Senior Advisor) al comandantului în toate problemele pe linie de geniu ale Diviziei Geniu (GENG Division). Este subordonat locțiitorului șefului de stat major pentru operații (Deputy Chief of Staff Operations - DCOPS Ops), împreună cu șeful informațiilor (G.2-Intelligence) și cu șeful operațiilor (G.3-Operations). Divizia Geniu este responsabilă pentru toate problemele pe linie de geniu ale comandamentului, inclusiv pentru aspectele întrunite, după cum este necesar.

\section{Structurile de geniu \\ din cadrul Comandamentelor \\ Corpurilor Multinaționale}

Comandamentele Corpurilor Multinaționale NATO au un grad ridicat de operaţionalizare și sunt în măsură să se disloce rapid la ordinul SACEUR, într-o zonă de operații alocată, pentru a conduce operații întrunite sau combinate ${ }^{20}$.

Acestea pot fi dislocate ca și: comandament al Corpului Multinațional, comandament pentru componenta terestră, comandament întrunit pentru structuri de forțe NATO, pentru a comanda o operație întrunită de mică amploare, și comandament capabil să sprijine o structură de comandă NATO, un Comandament de Forțe Intrunite, pentru conducerea unei operații întrunite majore, sau să augmenteze forțele pentru operațiile în desfășurare.

Aceste comandamente sunt conduse de un comandant cu grad de general cu trei stele (există și locțiitor al comandantului - general cu două stele), care este secondat de un șef de stat major (general cu două stele). În subordinea șefului de stat major, se află locțiitorii acestuia pe linie de planificare, operații și sprijin (generali cu o stea șefi de divizii) și alte divizii cu destinații speciale.

Diviziile sunt împărțite în servicii, conduse de ofițeri cu gradul de colonel. În funcție de comandament, Serviciul Geniu (G-ENG/Engineer 
Branch) se află în cadrul Diviziei Sprijin Luptă (NRDC-T) sau în cadrul Diviziei Operații $(\mathrm{NRDC}-\mathrm{GR})^{21}$.

Serviciul Geniu (G-ENG/Engineer Branch) din cadrul unui corp este condus de un șef al geniului care este și locțiitorul pentru geniu al șefului de stat major (Assistant Chief of Staff Engineer ACOS ENG) și are în compunere următoarele secții/birouri: Operații de Geniu (Engineer Operations); Planuri de Geniu (Engineer Plans); Infrastructură și Protecția Mediului (Infrastructure \& Environmental Protection); Informații de Geniu (Intelligence); Neutralizare Dispozitive Explozive (EOD).

Serviciul Geniu are încadrat, pe timp de pace, un număr mai mic de persoane, dar în eventualitatea dislocării sau declanșării unei situații de criză, acesta se va augmenta cu personal suplimentar. Serviciul Geniu are ca responsabilităţi curente monitorizarea și evaluarea necesarului de capabilități de geniu. Acesta asigură consiliere și sprijin de specialitate pentru protecția forței, CIMIC și pentru alte domenii specializate, la nevoie. Asigură consiliere pe linie de geniu, pentru probleme de protecție a mediului, și coordonarea acestui domeniu. De asemenea, asigură feedback pentru toate lecțiile identificate/ învăţate, pe linie de specialitate.

Serviciul Geniu planifică, coordonează și sincronizează toate acțiunile legate de sprijinul de geniu pentru a contribui la punerea în aplicare a planurilor de operații, care includ atât sprijinul de geniu pentru dezvoltarea și întreținerea infrastructurii în aria de responsabilitate (AOR), cât și sprijinul de geniu pentru asigurarea libertății de manevră/mișcare.

\section{Concluzii}

Conform politicilor pe linie de geniu, emise periodic de Comitetul Militar ${ }^{22}$, comandanții de la toate nivelurile ierahice (strategic, operativ și tactic) au nevoie de un consilier pe linie de geniu, respectiv șeful geniului, care, împreună cu un personal de stat major specializat, trebuie să fie în măsură să asigure o gestionare eficientă a resurselor de geniu. Experienţa arată că resursele de geniu sunt, de obicei, limitate, aşa că trebuie planificate şi întrebuinţate judicios. Eficacitatea personalului de geniu de la fiecare nivel va depinde de o bună coordonare și de o strânsă cooperare pe orizontală și pe verticală. Implicarea personalului de geniu pe parcursul întregului proces de planificare operațională este esenţială. Planificatorii sunt responsabili de implicarea geniştilor pentru sprijinul operațiilor planificate.

Şeful geniului din cadrul comandamentului Aliat de nivel strategic este responsabil pentru consilierea nemijlocită a comandantului și a echipei de comandă cu privire la toate problemele pe linie de geniu și, de asemenea, pentru îndrumarea şi coordonarea personalului de stat major de geniu din cadrul comandamentului.

La nivel operativ, personalul de geniu din cadrul comandamentelor de forţe întrunite trebuie să colaboreze permanent cu toate celelalte elemente ale statului major pentru a planifica, a coordona, a integra și a sincroniza sprijinul de geniu pe timpul desfășurării operației. Personalul de stat major de geniu din cadrul comandamentului de forţe întrunite trebuie, de asemenea, să coopereze și să se coordoneze îndeaproape cu autorităţile naţiunii gazdă, cu națiunile care contribuie cu trupe, cu organizaţiile civile și cu agențiile.

În cooperare cu personalul de stat major de geniu de la nivel operativ și cu personalul de stat major de geniu de la nivel tactic, şeful geniului de la nivelul grupării de forţe întrunite îşi exercită autoritatea de coordonare asupra tuturor structurilor de geniu din teatru.

\section{NOTE:}

1 *** MC 0560/2 Military Committee Policy for Military Engineering (Politica Comitetului Militar pentru geniu), 2017, p. 3.

2 Geniul la nivel strategic sau superior structurii de comandă NATO (the NATO Command Structure - NCS) este reglementat de Allied Command Operation Directive (AD) 084-001 Military Engineering.

$3 \mathrm{https}: / /$ nato.mae.ro/node/416, accesat la 03.11.2021.

4 NATO Encyclopedia 2014-2019, NATO Headquarters, Brussels, Belgium, passim.

5 *** AJP-3 (C), Allied Joint Doctrine for the Conduct of Operations, February 11, 2019, pp. 1-4 -1-6.

6 Ibidem.

7 *** AJP-3.12 (C), Allied Joint Doctrine for Military Engineering, 2021.

8 Ibidem, pp. 2-1 - 2-2.

9 Ibidem, pp. 2-2 - 2-3.

10 Prin operație de geniu se va înțelege totalitatea activităţilor genistice circumscrise unui obiectiv specific de sprijin de geniu al unei operații întrunite sau al operației unei mari unități de forțe luptătoare.

11 *** AJP-3.18, Allied Joint Doctrine for Explosive Ordnance Disposal Support to Operations. 
$12 * * *$ AJP-3.12 (C), Allied Joint Doctrine for Military Engineering, 2021, pp. 2-3 - 2.4.

$13 * * *$ AJP-3, Allied Doctrine Joint for Conduct of Operations, 2019.

14 *** AJP-3.12 (B), Allied Joint Doctrine for Military Engineering, 2014, p. 2-2.

15 Ibidem.

16 *** AJP-3.12 (C), Allied Joint Doctrine for Military Engineering, 2021, p. 2-2 - 2.3.

17https://jfcbs.nato.int; https://jfcnaples.nato.int; https:// en.wikipedia.org/wiki/Allied_Joint_Force_Command Naples, accesat la 03.11.2021.

18 *** The LANDCOM Handbook, Izmir, Turkey, 2019; https://lc.nato.int/, accesat la 03.11.2021.

19 Ibidem, pp. 97-100.

20 https://www.nato.int/cps/en/natohq/topics_50088. htm; http://www.hrf.tu.nato.int/vision-mission.html, accesat la 03.11.2021.

21 https://nrdc.army.gr/; http://www.hrf.tu.nato.int/ index.html, accesat la 03.11.2021.

22 *** MC 0560 MC Policy for Military Engineering, 2008; MC 560/1 - MC Policy for Military Engineering, 2012; *** MC 560/2 MC Policy for Military Engineering, 2017.

\section{BIBLIOGRAFIE}

*** AJP-3, Allied Doctrine Joint for Conduct of Operations, 2019.

*** AJP-3 (C), Allied Joint Doctrine for the Conduct of Operations, 11 February, 2019.

*** AJP-3.12 (B), Allied Joint Doctrine for Military Engineering, 2014.

*** AJP-3.12 (C), Allied Joint Doctrine for Military Engineering, 2021.

*** AJP-3.18, Allied Joint Doctrine for Explosive Ordnance Disposal Support to Operations.

*** APP-6, NATO Glossary of Terms and Definitions, 2019.

*** ATP-3.12.1 Allied Tactical Doctrine for Military Engineering, 2016.

*** ATP-3.2.2, Command and Control of Allied Land Forces, Edition B Version 1, 2016.

*** Brussels Declaration on Transatlantic Security and Solidarity, NATO Public Diplomacy Division, Brussels, Belgium, 11 July 2018.
*** MC 0560 MC Policy for Military Engineering, 2008; MC 560/1 - MC Policy for Military Engineering, 2012.

*** MC 0560/2 MC Policy for Military Engineering, 6 September 2017.

*** NATO Encyclopedia 2014-2019, NATO

Headquarters, Brussels, Belgium.

*** NATO Summit Guide, Warsaw, 8-9 July 2016, NATO Public Diplomacy Division, Brussels, Belgium, 2016.

*** Strategic Concept for the defence and Security of Members of the North Atlantic Treaty Organization Adopted by Heads of State and Government at the NATO Summit in Lisbon 19-20 November 2010, NATO Public Diplomacy Division, Brussels, Belgium, 2010.

*** The LANDCOM Handbook, Izmir, Turkey, 2019.

*** The Secretary General's Annual Report 2011-2019, NATO Public Diplomacy Division, Brussels, Belgium.

https://www.nato.int

http://www.mae.ro/sites/default/files/file/pdf/

TRATATUL $\% 2520$ NORD-ATLANTIC.pdf

https://www.mae.ro/node/5337

https://shape.nato.int

https://www.act.nato.int/

https://jfcbs.nato.int

https://jfcnaples.nato.int

https://lc.nato.int/

https://www.nato.int/cps/en/natohq/structure.htm

https://shape.nato.int/military_command_ structure

https://nrdc.army.gr/

http://www.hrf.tu.nato.int/index.html

https://en.wikipedia.org/wiki/Allied_Joint_

Force_Command_Naples.

https://en.wikipedia.org/wiki/Allied_Joint_

Force_Command_Brunssum

https://www.nato.int/cps/en/natohq/topics 50088.htm

http://www.hrf.tu.nato.int/vision-mission.html https://lc.nato.int/ 